\title{
Why Study Lakes? An Overview of USGS Lake Studies in Wisconsin
}

\author{
By H. S. Garn, J. F. Elder, and D. M. Robertson, Lake Studies Team, U.S. Geological Survey, Wisconsin District
}

\section{Wisconsin Lakes - a Natural Treasure}

Wisconsin's 15,000 lakes are prominent features in its landscape and an important public resource. In the northern part of the State, the recent glaciation (ending about 10,000 years ago) created one of the densest clusters of lakes found anywhere in the world, containing lakes that occupy depressions in the glacial moraines and outwash deposits (fig. 1). This Northern Lakes and Forests Ecoregion contains more than 80 percent of the State's lakes (Wisconsin Department of Natural Resources, 2001). South of this ecoregion, there are fewer lakes, but they still are common. Usually situated in agricultural or urban landscapes, lakes in southern Wisconsin generally have higher levels of nutrients and alkalinity, and higher biological productivity than their northern counterparts. For most lakes in Wisconsin, phosphorus is the nutrient that limits algal growth (Lillie and Mason, 1983).

Lakes are highly valued for their recreational, aesthetic and scenic qualities, and the water they contain is one of the most treasured of our natural resources (fig. 2). Lakes constitute important habitats and food resources for a diverse array of fish, aquatic life, and wildlife, but lake ecosystems are fragile. Lake ecosystems can undergo rapid environmental changes, often leading to significant declines in their aesthetic, recreational, and aquatic ecosystem functions. Exposed to external effects from the atmosphere, their watersheds, and ground water, lakes are subject to change through time. Human activities can further accelerate the rates of change. If the causes of the changes are known, however, human intervention (lake-management practices) sometimes can control, or even reverse, detrimental changes.

Limnology (the study of lakes and other freshwater systems) is the science that can provide improved understanding of lake ecosystem dynamics and information that can lead to sound management policies. As more studies are conducted on a variety of lake systems, the accumulated information leads to the development of general concepts about how lakes function and respond to environmental changes.

The condition of a lake at a given time is the result of the interaction of many factors-its watershed, climate, geology, human influence, and characteristics of the lake itself. With constantly expanding databases and increased knowledge, limnologists and hydrologists are able to better understand problems that develop in particular lakes, and further develop comprehensive models that can be used to predict how lakes might change in the future.

While the development of a limnological database and knowledge is important, no amount of generalization can provide a full understanding or predict conditions of any particular lake. Each lake system is unique, and its dynamics can be understood only to a limited degree based on information from other lakes. Just as a physician would not diagnose an individual's medical condition or prescribe treatment without a personal medical examination, a limnologist or hydrologist cannot accurately assess a lake system or suggest a management strategy without data and analysis from that particular lake and

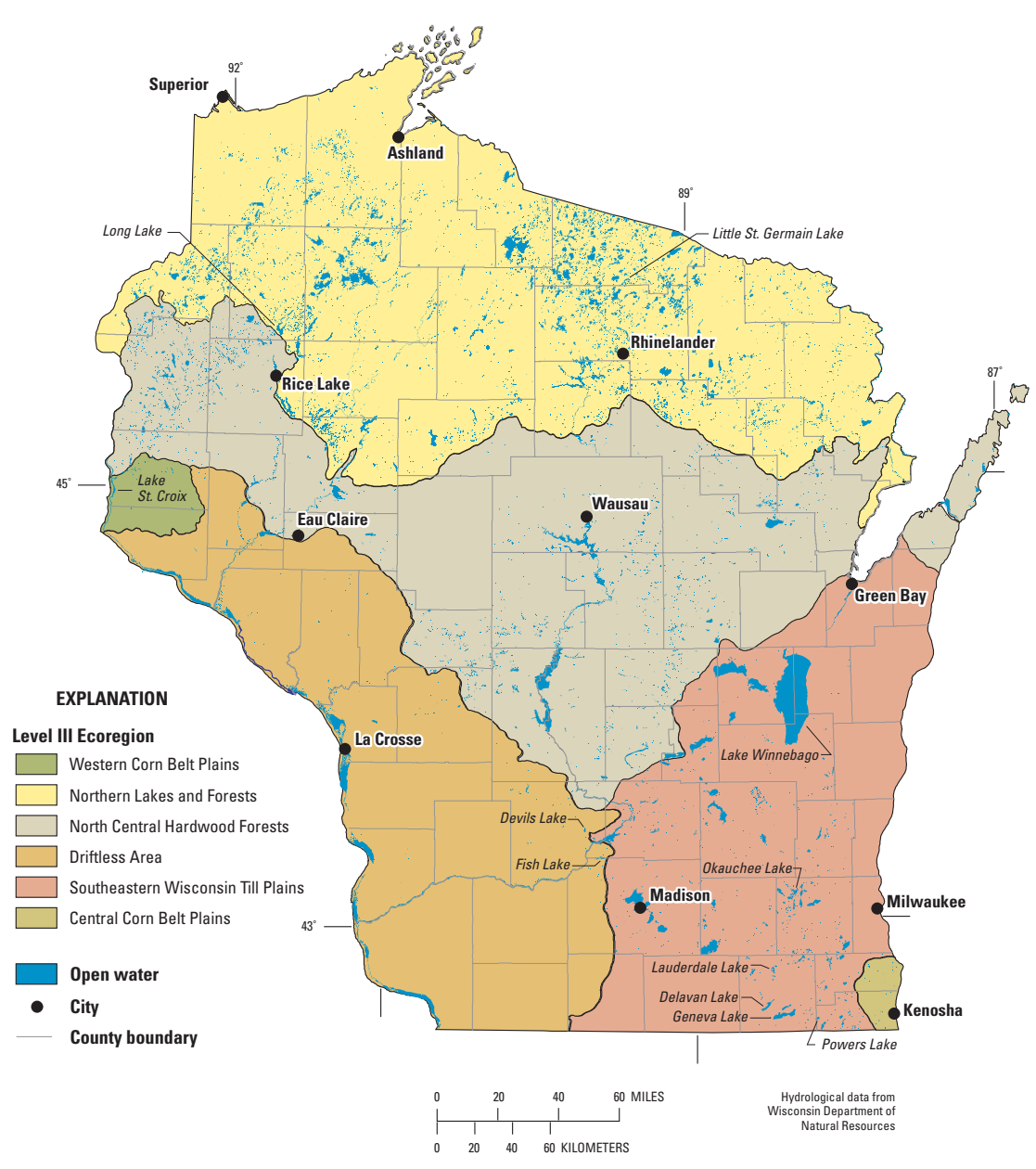

Figure 1. General distribution of lakes in relation to ecoregions of Wisconsin (adapted from Omernik and others, 2000). 


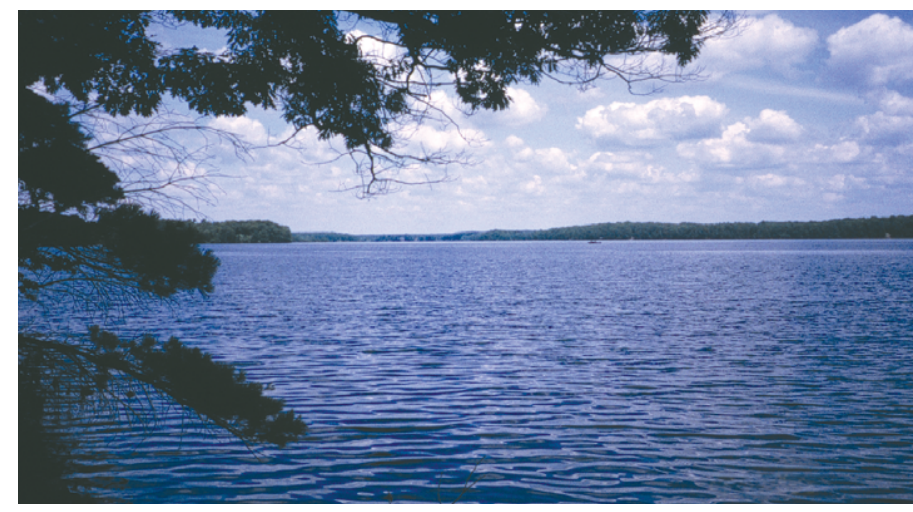

Figure 2. Long Lake, in northern Wisconsin, is a natural resource with high water quality, valued for its recreational, aesthetic and scenic qualities.

its environment. The following are some of the most important basic factors that give unique character to each lake ecosystem.

- Climate - Temperature, wind, precipitation, and solar radiation all critically affect the lake's hydrologic and chemical characteristics, and indirectly affect the composition of the biological community. Precipitation is the main factor affecting runoff and the delivery of nutrients and sediments. Temperature, wind, and energy from the sun affect lake stratification and mixing, plant growth, and evaporation.

- Atmospheric inputs - The surface of a lake is directly exposed to atmospheric inputs. Not only wet precipitation, but also dry particles, can be major sources of certain contaminants to a lake. Each lake also receives indirect atmospheric inputs by way of the runoff from its watershed.

- Geologic substrate and soils in the basin - The soil type affects the potential for runoff and erosion. The physical characteristics of the substrate determine the extent, nature, and quality of ground-water inflows and outflows. These are primary factors affecting the lake's chemistry, because of transfers between water and sediments, and input of sediment, minerals, and nutrients from the watershed by runoff water flowing into the lake.

- Physiography - The area, surface topography, existence of upstream lakes and wetlands, altitude, and land slope of the lake's watershed affect surface-water runoff and the amount and nature of chemicals and sediments entering the lake. The physiography of the region affects the size of a lake's watershed and ground-water contributing area. The boundaries of a lake watershed and ground-water contributing area may not necessarily coincide. Interactions with land use by people can appreciably change how these factors affect runoff and the export of nutrients and sediment.

- Land use - The type, location, extent, and history of land cover/land use (such as agriculture, rural, and urban developed areas) can greatly affect the quantity of surfacewater and ground-water inflows and outflows, as well as the amounts and types of sediment, nutrients and chemicals (natural or synthetic) that are transported into the lake from the watershed.
- Lake morphometry -Size, shape, and depth characteristics of a lake are critical in determining currents and mixing of the lake, as well as its thermal and chemical stratification characteristics.

\section{Common Environmental Problems in Lakes and Probable Causes}

Eutrophication is the natural process of physical, chemical, and biological changes ("aging") associated with nutrient, organic matter, and silt enrichment of a lake. If the natural process is accelerated by human influences, it is termed "cultural" eutrophication. Lakes are subject to a variety of physical, chemical, and biological problems that can diminish their aesthetic beauty, recreational value, water quality, and habitat suitability. Among the most common lake problems, and the conditions that often occur with eutrophication are the following.

- Algal blooms - Extensive and rapid growth of planktonic (floating and suspended) algae, caused by an increased input of nutrients (primarily phosphorus, but occasionally can also be caused by nitrogen), is a common problem in lakes (fig. 3). Lakes normally undergo aging over timescales of centuries or thousands of years, but the process can be accelerated rapidly to only decades by human activities that cause increases in sedimentation and nutrient inflow to the lake. Accelerated eutrophication and excessive algal growth reduces water clarity, inhibits growth of other plants, and can lead to extensive oxygen depletion, accumulation of unsightly and decaying organic matter, unpleasant odors, and fish kills.

- Sedimentation/turbidity - Increases in accumulation and/or resuspension of sediments can be a detriment to water quality and habitat for many aquatic species. Such events usually are caused by heavy rains that produce erosion and intense runoff, carrying heavy sediment loads into lakes. High winds, boating activity, and bottom-feeding fish, such as carp, may also resuspend bottom sediments and increase turbidity.

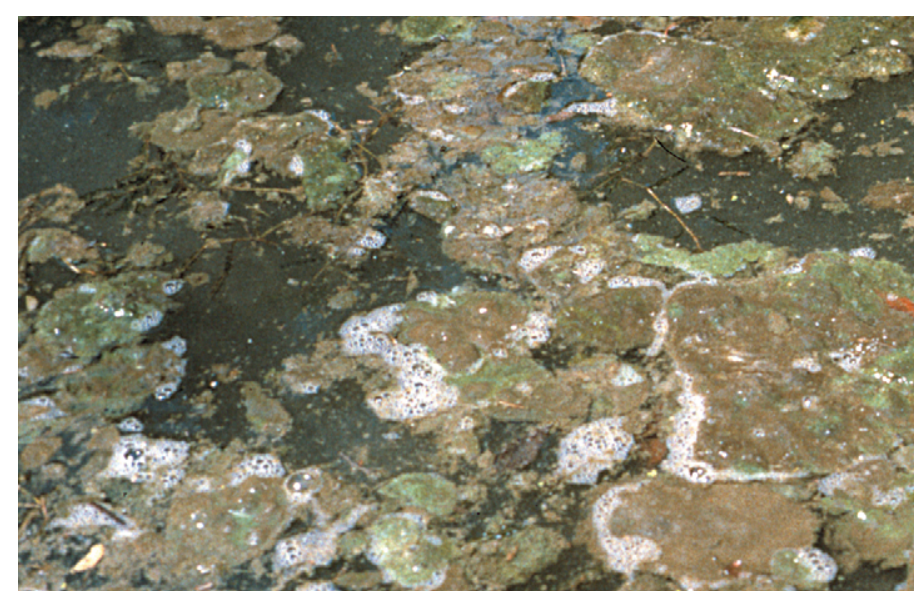

Figure 3. Algal bloom and degraded water quality of a lake affected by nutrient enrichment. 
- Oxygen depletion - Decreases in dissolved oxygen to less than $3 \mathrm{mg} / \mathrm{L}$ (milligrams per liter) in the water can be harmful or lethal to many desirable species of aquatic life. The primary mechanism of oxygen loss is consumption by high rates of respiration and organic decomposition. Ideally, such consumption is offset by oxygen inputs from the atmosphere and from photosynthesis by aquatic plants. However, in stratified lakes, the atmospheric source is cut off from the hypolimnion (deep lake layer), and oxygen concentrations in the hypolimnion may decline to zero (anoxia) until the lake mixes again. Under anoxic conditions, phosphorus may be released from the bottom sediments into the overlying water. This "internal loading" may be considerable with phosphorus-enriched sediments and prolonged anoxia. Prolonged low oxygen concentrations in the summer or under ice in the winter can lead to fish kills.

- Growth of aquatic plants (macrophytes) - Normal macrophytic growth generally is beneficial for the lake ecosystem; among other benefits, the plants provide refuge for fish and other organisms. However, in some lakes, the growth of aquatic plants ("weeds") can become excessive and create a serious nuisance for lake users, interfering with swimming, boating, and other recreational activities. Excessive macrophytes commonly are caused by increased nutrients, invasion of exotic species, or accumulation of organic sediment. The improvement of water clarity resulting from management actions designed to control algal production can provide better conditions for growth of rooted plants.

- Water-level changes - Wide fluctuations in stage (lake level) can create major hardships for lakeside residences, marinas, and businesses, and they also may impair the habitat suitability for nearshore biota. These changes most commonly are linked to weather anomalies (extended periods of abnormally high or low precipitation), but also may be associated with human activities such as withdrawals for water use.

- Species shifts - Populations of desirable animal and plant species might decline sharply or disappear, to be replaced by other species. Usually, the new dominant species will become a nuisance and degrade some or all desirable qualities of the lake. Species shifts can be caused by introduction of invasive species that may have little or no natural controls on their population growth, or are stimulated by changes in environmental conditions (for example, climate changes, acidification from "acid rain" or other changes in water chemistry, or physical changes).

To diagnose or identify causes of problems, one must understand the processes and interactions within the lake (among its morphometry, water quality, algae, macrophytes, fish, and other fauna) and those between the lake and its watershed (quantity and quality of inputs from precipitation, surface water, ground water, and other localized sources). A combination of natural factors within the watershed and the lake may be acting to produce a fertile lake, and there may be little opportunity to improve its water-quality condition by management actions. However, if human activities and developments creating hydrologic modifications or increasing sediment and nutrient inputs are the cause of accelerated eutrophication, then these effects may be reduced by management measures in the watershed and (or) the lake. Qualitative and quantitative limnological and hydrological investigations can help to differentiate between natural and human-caused problems and to identify possible solutions.

\section{Purposes, Objectives, and Design of Lake Studies}

Lake studies are conducted to meet specific purposes, or combinations of purposes, that support management activities and decisions made by a lake association, lake district, or other private or governmental organizations. Among the most common of these purposes are as follows.

- Development and implementation of lake-management plans

- Protection of present water quality

- Restoration of former water quality

- Watershed (land-use) planning and management

- Wetland protection or restoration

- Lake classification and local ordinance development

- Protection of fish and wildlife and their habitats

The success of any lake study depends on development of appropriate objectives, based on careful attention to the overall purpose(s) of the study. A study plan, selection of methods, and a data-collection program for the lake and its watershed then can be developed to acquire the information necessary to achieve these objectives. Objectives of lake studies generally include one or more of the following.

- Assess current physical, chemical, and biological conditions

- Determine how conditions are changing with time

- Assess watershed characteristics (hydrology, water quality, land uses, nutrient and sediment yields, and sources of nutrients)

- Identify problems and opportunities for lake improvement

- Determine causes of lake problems, and provide information that can be used to design management actions, if any, that are feasible and likely to be successful in treating the lake's problems

- Evaluate the effectiveness of implemented management measures and determine whether they are performing as planned

Lake studies vary considerably in the amount and detail of information gathered. The design of the study depends on its purpose and objectives. Decisions about the types and frequency of data collection should be made based on a cost/benefit assessment of each item-do these data contribute to fulfillment of the purpose and are their contributions sufficient to justify the cost and effort of collecting them? The accuracy of results needed from the study and the methods to be used (whether to 
rely on estimated rather than measured data) depend on the type and severity of problems, and the social and economic effects of decisions (management actions) that need to be made to address the problems.

\section{Types of Lake Studies}

Lake studies by the U.S. Geological Survey (USGS), Wisconsin District Lake Studies Team are conducted to achieve many of these objectives, and generally fall into various levels or types of studies, from simple to complex (summarized in table 1). Each level grades to the next and may include components of the type of study done in the lower levels, as well as additional investigations. The Team's mission is to provide hydrologic, water quality, and other scientific information to help describe current characteristics and conditions of lakes, help identify and understand problems, and help determine effective management actions to protect or restore lakes in Wisconsin and the Nation. Information about the Wisconsin District Lakes Program can be found at http://wi.water.usgs.gov/ projects/index.html. Nationally consistent laboratory procedures and quality control are used by the USGS in conducting these studies. The standards ensure that all data are directly comparable from region to region in the country, and available from national USGS databases.

Table 1. General summary of the types of lake studies and approaches used by the USGS Wisconsin District Lake Studies Team to address study objectives

\section{Monitoring studies}

Objective: Assess current conditions and evaluate trends

Approach: Monitoring by USGS, volunteers (self-help), State or other agencies; compare with other available data.

\section{Diagnostic studies}

Objective: Identify causes of problems

\section{Approaches:}

A. Qualitative and semi-quantitative evaluation of sources of problems. Use limited monitoring and data from other studies, compute water and nutrient budgets from estimated data.

B. Quantitative evaluation of sources of problems. Monitoring measures major components of water and nutrient budgets to provide greater resolution of sources and causes.

\section{Feasibility studies}

Objective: Evaluate feasibility of possible solutions and effectiveness of management practices

Approach: Incorporate many activities from the diagnostic approach above plus evaluation of likely solutions. Monitor and evaluate the effectiveness of improvement measures.

\section{Monitoring Studies}

Studies to assess current conditions and trends may be referred to as monitoring studies because they usually entail collection of data (monitoring), but little or no investigation of causes of problems, processes, or ecosystem dynamics. Whether the study involves monitoring of only lake stage, or a range of chemical and biological variables, it essentially is an informational study. Monitoring may include review and evaluation of available data, lake-level monitoring, and monitoring of in-lake physical, chemical, and biological variables useful for describing the condition (typically trophic status) of the lake, and comparing trophic state indicies (Carlson, 1977) with other lakes in the region. Interpretation of the data generally is limited to analysis of in-lake characteristics and possibly trends (how the variables might be changing over time) if sufficient data are available. Long-term data collection (greater than 5 years), using

Table 2. Commonly measured variables for monitoring lakes, and usual depth intervals where sampled

[NS, near surface; NB, near bottom; profile, multiple depths at one site, from surface to bottom; Sed, in bottom sediments; TSI, trophic state index; A, as appropriate for species sampled]

Variable Depth

1. Water level (stage)

water surface

\section{Common field and TSI variables:}
A. Water transparency
NS
(Secchi depth, light penetration)
B. Water temperature
profile
C. Dissolved oxygen
profile
D. $\mathrm{pH}$ (acidity)
E. Specific conductance
profile
F. Chlorophyll ${ }^{1}$
profile
NS

3. Chemical variables:
A. Nutrients (phosphorus, nitrogen)
NS, NB, intermediate
B. Major cations and anions
NS/NB
C. Organic carbon
NS/NB, Sed
D. Synthetic organic compounds
NS/NB, Sed
E. Trace elements, metals
NS/NB, Sed

4. Ecological/biological variables
A. Phytoplankton (algae/floating plants)
NS
B. Macrophytes
(plants rooted in lake bottom)
C. Primary productivity ${ }^{2}$
near-shore area
D. Attached algae
NS
E. Benthic organisms
bottom
(bottom-dwelling animals)
F. Zooplankton (small animals, usually crustaceans, in water)
G. Fish
$\mathrm{NB} / \mathrm{Sed}$
A A

\footnotetext{
${ }^{1}$ usually chlorophyll $a(\mathrm{Chl} a)$ - a measure of density and activity of algae ${ }^{2}$ primary productivity (PPR) - a measure of photosynthesis; (less common measurement than $\mathrm{Chl} a$ )
} 
Figure 4. Measurement of lake water-quality profiles with a multiparameter water-quality instrument.

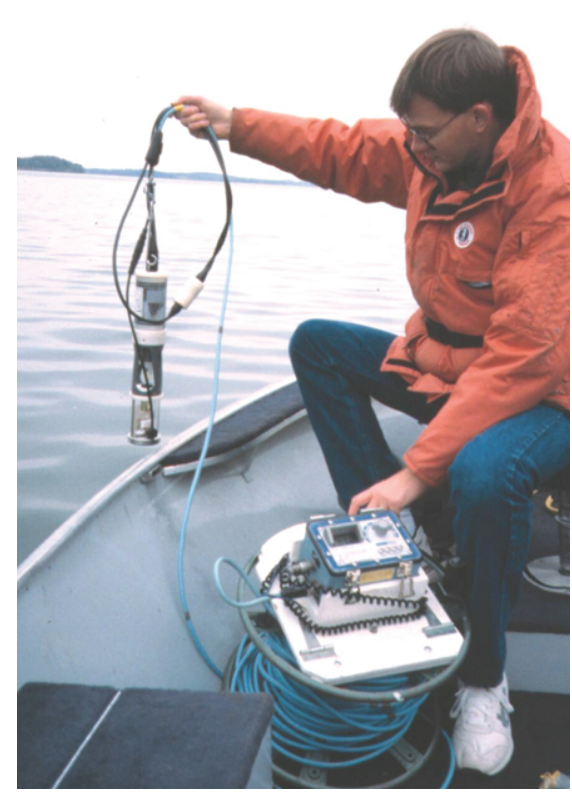

consistent and comparable methods, is critical for differentiating real trends from short-term climatic fluctuations. Trend analysis becomes continually more meaningful and valuable as the length of time of monitoring increases.

Stage (lake-level) monitoring. This kind of data collection involves monitoring of water level (stage) of the lake, and how it changes over time. Stage monitoring also is used to determine changes in volume of lakes when computing water budgets. These data can be readily and accurately obtained with a staff gage read by an observer, or a stage recorder, which enables automatic collection of continuous data at frequent preset time intervals. It is particularly important to maintain the same datum over the period of record at a gage. Devils Lake in Sauk County, and Fish Lake in Dane County are examples of lakes that have been in this program for many years (Wisconsin District Lake Studies Team, 2002).

In-lake water-quality monitoring. This effort routinely involves collection of data on physical, chemical, and biological variables at intervals during the year. Sampling times for most lakes are commonly during late winter (to determine conditions under ice cover), at spring overturn when the lake is mixed, and monthly during the summer (June through August). The list of variables to monitor and sampling frequencies may be modified for each lake, depending on the characteristics of the lake and problems experienced.

Physical, chemical, and biological variables that may be monitored in lakes to fulfill certain study purposes are listed in table 2 . Items $1,2,3 \mathrm{~A}$, and $3 \mathrm{~B}$ in the table commonly are included in many lake monitoring studies. Depth profiles of field variables can be measured quickly on-site with multiparameter instruments. These variables are measured at closely spaced intervals (generally $0.5-1$ meters depending on the depth of the lake) from the surface to the bottom, to determine changes in temperature, dissolved oxygen, $\mathrm{pH}$, and specific conductance with water depth (figs. 4 and 5). Other variables that require collection of water samples and analyses in the laboratory, particularly chemical (such as phosphorus and nitrogen) and biological samples, commonly are sampled at two or more depths.

The profile measurements and samples generally are taken at a representative site, located at or near the deepest part (the "deep hole") of the lake. Additional monitoring may be done at other sites in strategic locations to characterize specific features of the lake system, such as inflows and outflows, multiple deep basins, or additional bays of complex-shaped lakes (Holdren, Jones, and Taggart, 2001).

Data from these measurements and samples provide a basis for scientific assessment of lake condition and common lake problems. For example, profile data may show the extent of dissolved oxygen depletion over the summer, and nutrient data may identify high concentrations of available phosphorus for algal growth or phosphorus release from bottom sediments. Combined with data on water transparency (Secchi depth) and algal pigment (chlorophyll $a$ ), these data support calculation of the lake's trophic state index (TSI) (fig. 6), which is a quantitative, objective measure of the current state of the lake in the eutrophication process. Okauchee Lake in Waukesha County is an example of a lake in this study type with long-term data. This lake has been monitored for water quality since 1984 (Wisconsin District Lake Studies Team, 2002). About 100 lakes throughout the State have been monitored at this level by the USGS since mid-1980.
2-12-01

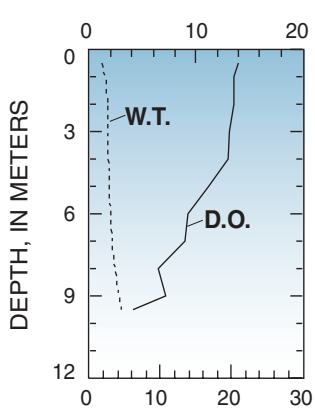

4-10-01

6-19-01

7-26-01

DISSOLVED OXYGEN CONCENTRATIONS (D.O.) IN MILLIGRAMS PER LITER
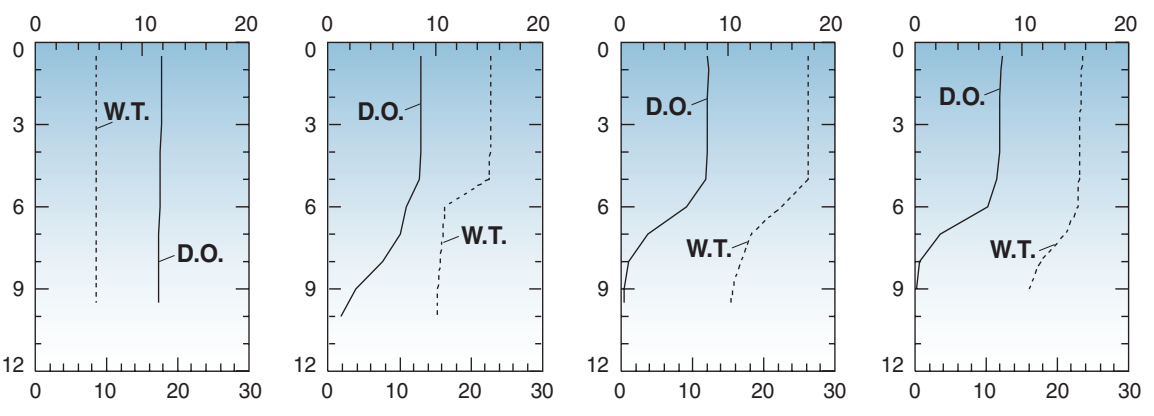

WATER TEMPERATURE (W.T.) IN DEGREES CELSIUS

Figure 5. Graphs showing typical profile data for water temperature and dissolved oxygen (Powers Lake, Kenosha County, Wis.). 

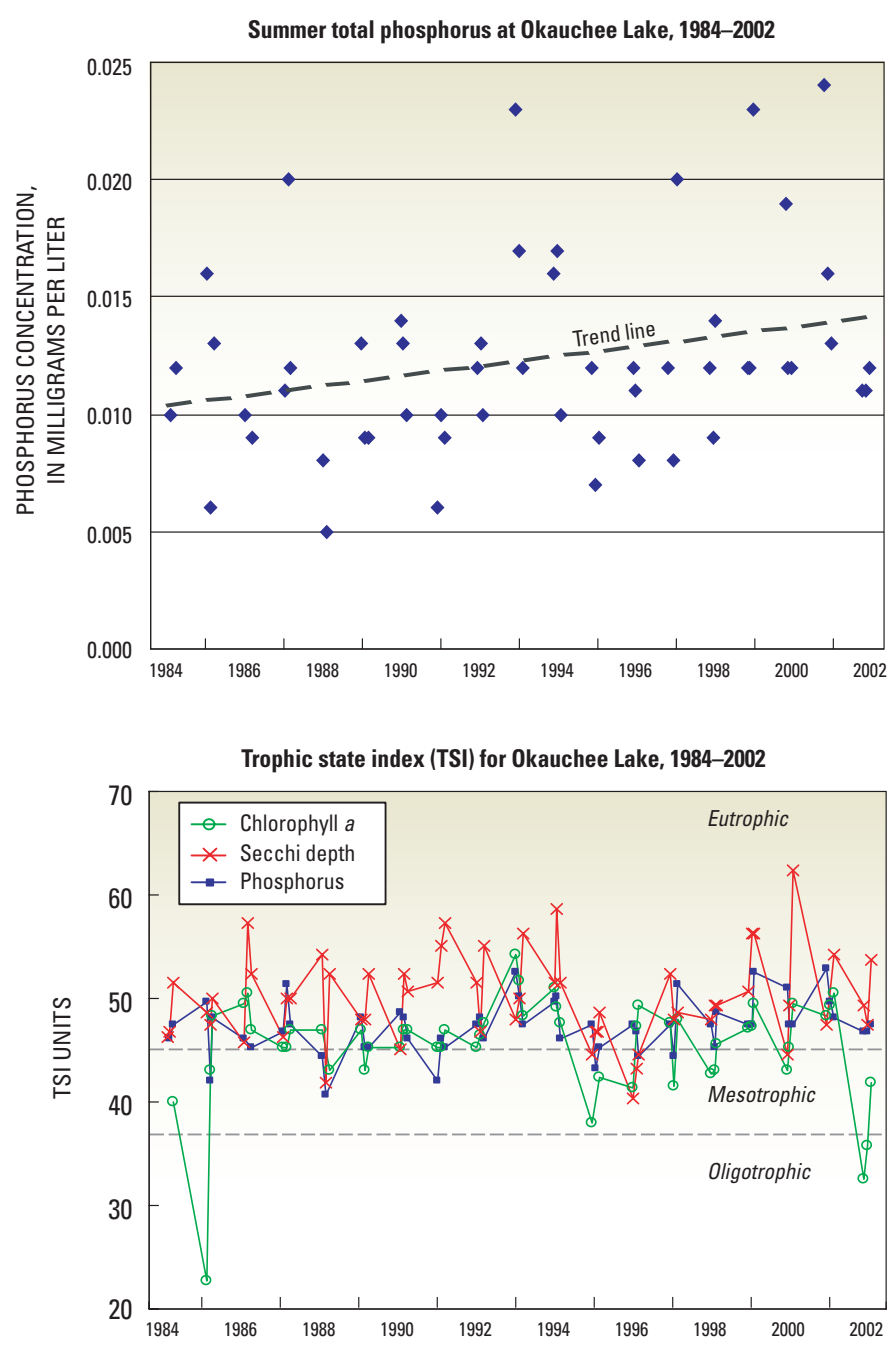

Figure 6. Total phosphorus and trophic state index (TSI) data for Okauchee Lake, Waukesha County, Wis., 1984-2002.

\section{Diagnostic Studies}

Studies to diagnose problems and identify possible solutions, generally termed diagnostic studies, extend beyond monitoring to include more complex data collection, analysis of the hydrologic system and processes, and interpretation. The objectives of these studies usually include quantifying the problems, defining causes of the problems, and identifying possible solutions. Results commonly are used in the development of lake-management plans. These studies usually include basic data collection, but the studies go further, to include searches for answers to questions such as: How severe are the problems? What are the major sources of nutrients and causes of the problems? What are the most likely solutions?

Diagnostic studies commonly include activities that:

- monitor and quantify the major inflows to and outflows from the lake to develop a detailed water budget for the lake;

- determine phosphorus and sediment loads associated with major water inflow and outflow source, and develop a detailed phosphorus budget for the lake, thereby providing a better understanding of the problems and sources of nutrients;
- evaluate lake water quality in relation to water and nutrient loading by the use of lake water-quality models, such as the Wisconsin Lake Modeling Suite, WiLMS (Panuska and Kreider, 2002).

Methods used in studies at this level vary greatly and may include both qualitative and quantitative methods based on estimates from the literature and previous studies, and on monitored data. Studies are designed to fit the hydrologic conditions, severity of problems, accuracy desired, and objectives of the study. Various components of the water and phosphorus budgets may be estimated or measured. Phosphorus usually is the nutrient that limits algal growth (Guildford and Hecky, 2000). Precipitation is measured by a recording rain gage or estimated from nearby National Weather Service station data. Phosphorus input from precipitation is estimated from published values. Evaporation usually is estimated from published evaporation values. Surface-water inflow and outflow may be determined by recording streamflow-gaging stations (fig. 7) near the mouths of major tributaries and at the lake outlet. Surface-water flows are sampled and analyzed for phosphorus and sediment concentrations. Streamflow data, along with the concentration data, are used to determine the annual phosphorus inputs and losses. Phosphorus input (load) from surface water may be estimated by a regression approach (Cohn and others, 1989; Robertson and Roerish, 1999) with limited concentration data collected manually, or may be computed more accurately by using an integration technique (Porterfield, 1972) with extensive concentration data from frequent water sampling by observers or automatic water samplers. Inflow from small unmonitored watershed areas usually is estimated through the use of runoff coefficients using data from the nearby gaged watersheds, or tributary loads may be estimated by applying unit-area loads from previously monitored small watersheds (Corsi and others, 1997).

Net ground-water flow to the lake may be calculated as the residual in the water-budget equation, or determined by analyzing water-level data from piezometers (small-diameter wells, usually 1 inch or less) installed around the periphery of the lake and applying a two-dimensional ground-water-flow model, such as GFLOW (Haitjema, 1995) to the area. Water from nearshore piezometers is sampled and analyzed to measure phosphorus concentrations in ground water and to determine the loading

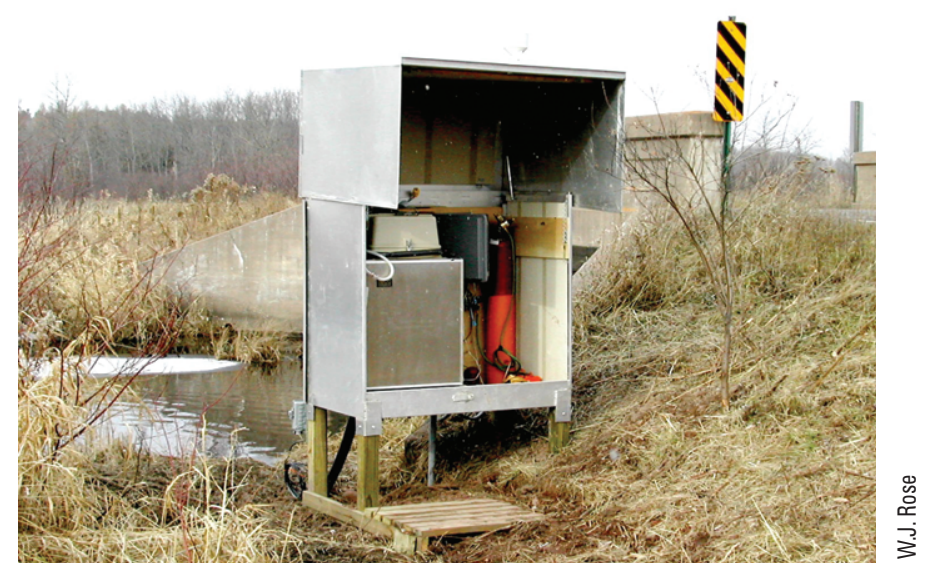

Figure 7. Typical U.S. Geological Survey recording streamflow-gaging station with automatic water sampler for load determinations. 
from ground water. Data for the flows and loads from the various sources are then used to construct water and phosphorus budgets for the lake (fig. 8).

Qualitative and semi-quantitative study approaches to evaluate problems are appropriate for lakes with less-severe problems and lower-cost solutions, where less-accurate results may be adequate (table 1). Quantitative study approaches, where major water and nutrient-budget components are measured directly, provide greater accuracy of results but at a higher cost. These studies are more appropriate for lakes with severe, complex problems. Diagnostic studies may typically require 3 to 5 years to complete.

Information and data discussed above are essential for understanding lake problems, identifying major sources and the relative importance of nutrient inputs, and identifying effective management strategies that can be used for developing lake and watershed management plans. Examples of recently completed lake diagnostic studies are Muskellunge and Little St. Germain Lakes in Vilas County (Robertson and Rose, 2000; 2003), Lake St. Croix in western Wisconsin (Robertson and Lenz, 2002), and Lauderdale Lakes in Walworth County (Garn and others, 1996). Diagnostic studies have been conducted by the USGS for about 25 lakes in Wisconsin.

\section{Feasibility Studies}

Studies to evaluate the feasibility and effectiveness of management measures, referred to as feasibility studies, go beyond diagnostic studies but generally incorporate many of the same activities. Studies include objectives similar to diagnostic studies, but also may include greater definition of the problems and causes, evaluation of solutions, and model simulation of future conditions. These lakes generally have more complex lake and watershed factors affecting water quality and usually have multiple or severe problems. Expensive restoration and protection measures often are being considered in such lakes, or they may already be in progress. These studies often are longer term than those for diagnostic studies, and may include monitoring to evaluate the effectiveness of implemented management measures (such as watershed practices that reduce nutrient loading, lake aeration, or treatment of bottom sediment). The studies may address questions such as: How has the lake changed in recent years or decades, and how do those changes relate to environmental changes, watershed characteristics, or land uses? What management measures would be most effective? Are treatments working as planned? What kinds of changes can be expected in the future? Various kinds of modeling techniques (watershed models, ground-water models, and lake models) may be applied to predict water-quality changes based on collected data and to evaluate the feasibility of solutions, thus providing information that can be used to design treatments.

These studies commonly include the components of diagnostic studies, but additionally include activities that:

- describe historical changes in lake water quality resulting from outside effects;

- relate the measured water and contaminant loads to observed and modeled water quality within the lake; and

- apply a calibrated lake model to predict how potential increases or decreases in phosphorus loading may effect the trophic status of the lake.
Lake water-quality models, such as BATHTUB (Walker, 1996) or the Wisconsin Lake Modeling Suite, WiLMS (Panuska and Kreider, 2002) may be used to evaluate and predict lake water quality relative to different phosphorus-loading scenarios. Interpretation may include assessment of probable responses to increases or decreases in nutrient loading that might result from various development and management scenarios within the lake's watershed, and prediction of probable outcomes of different management strategies. Lake studies at this level have been conducted at Delavan Lake (Robertson and others, 2000) and Geneva Lake in Walworth County (Robertson and others, 2002).

\section{Sources of Funding}

Two popular programs in Wisconsin that help fund lake studies are those of the Wisconsin Department of Natural Resources, Lake Planning and Protection Grant Program, (described at http: //www.dnr.state.wi.us/org/water/fhp/lakes/lkgrants.htm) and the USGS Cooperative Water Program. State grants can provide up to 75-percent funding to lake districts, lake associations, and other qualified local organizations and agencies for lake planning and management activities; the remaining 25 percent of project cost is provided by the local agency or lake district. The USGS Cooperative Water Program is a long-standing partnership between USGS and State and local governments for funding data collection and water-resources studies. Under this program the USGS may provide matching funding presently up to 40 percent of the total cost of the study to collect hydrologic data and conduct investigations, in cooperation with any local or State agency.
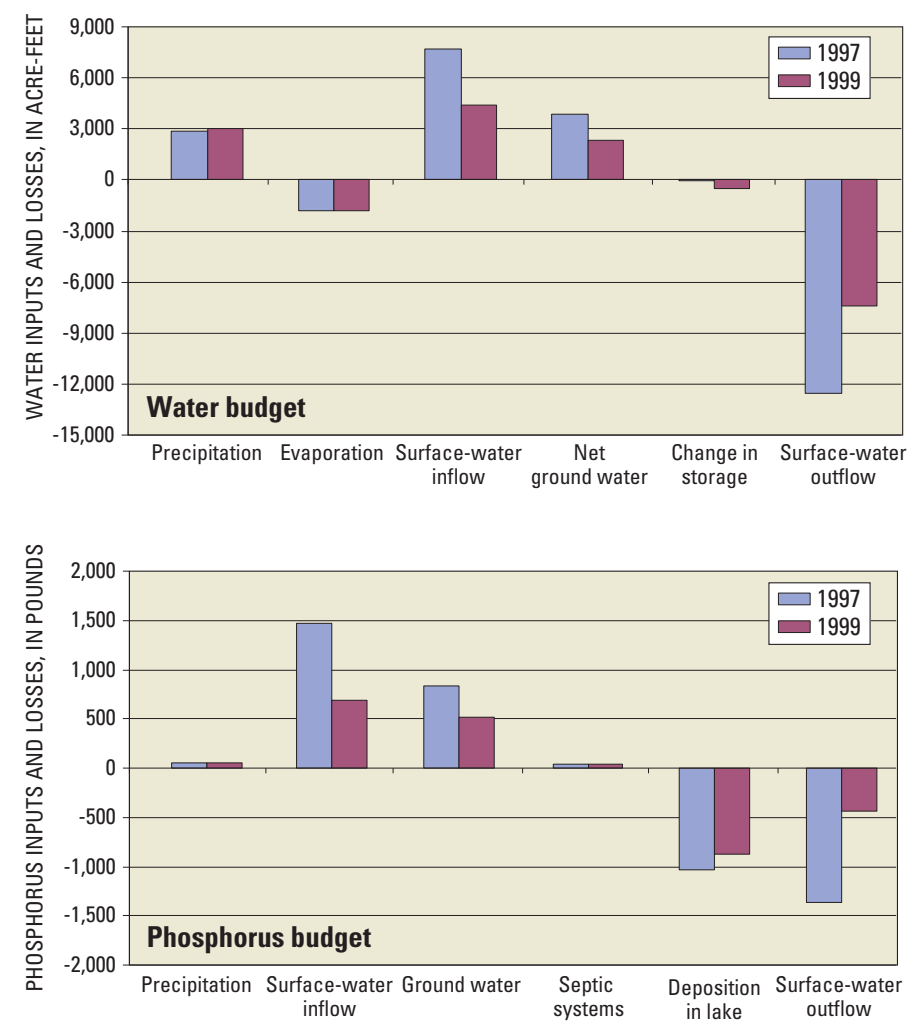

Figure 8. Hydrologic and phosphorus budgets of Little St. Germain Lake, Wis., 1997 and 1999 (from Robertson and Rose, 2000). 


\section{Lake Studies - an Investment for the Future}

Preservation of our lakes for their beauty and recreational benefits, as well as for their value as habitats for fish and wildlife, is of paramount importance. During the past century, our understanding of lakes has advanced considerably. Whereas we once were relatively unaware of the sensitivity of lakes to disturbances within their basins and watersheds, we are now much more alert to this sensitivity, and, consequently, we are more careful about actions that could accelerate lake deterioration. Lake studies, which contribute to general and specific knowledge of lake systems, require commitment of considerable effort and funding, but this commitment leads to major improvement of the likelihood of developing successful lake-management strategies and avoiding costly problems in the future. The goal of lake monitoring is to identify small changes in conditions so that remedial work can start before a lake has degraded extensively and expensive restoration measures are necessary. Lake monitoring is an investment for the future with potential for high returns.

"The future water quality of Wisconsin's lakes lies in the wise management of our natural resources. Shoreline and landuse management, nonpoint-source pollution control, and control of toxic wastes are all critically important elements in protecting Wisconsin's many lakes.” (Lillie and Mason, 1983)

\section{Acknowledgments}

The authors thank colleague reviewers P.J. Garrison and P.W. "Buzz" Sorge, Wisconsin Department of Natural Resources, and W.J. Rose, U.S. Geological Survey for their helpful review comments.

\section{References}

Carlson, R.E., 1977, A trophic state index for lakes: Limnology and Oceanography, vol. 22, no. 2, p. 361-369.

Cohn, T.A., Delong, L.L., Gilroy, E.J., Hirsch. R.M., and Wells, D.K., 1989, Estimating constituent loads: Water Resources Research, v. 25, no. 5, p. 937-942.

Corsi, S.R., Graczyk, D.J., Owens, D.W., and Bannerman, R.T., 1997, Unit-area loads of suspended sediment, suspended solids, and total phosphorus from small watersheds in Wisconsin: U.S. Geological Survey Fact Sheet FS-195-97, 4 p.

Garn, H.S., Olson, D.L., Seidel, T.L. and Rose, W.J., 1996, Hydrology and water quality of Lauderdale Lakes, Walworth County, Wisconsin, 1993-94: U.S. Geological Survey WaterResources Investigations Report 96-4235, 29 p.

Guildford, S.J. and R.E. Hecky. 2000, Total nitrogen, total phosphorus, and nutrient limitation in lakes and oceans: Is there a common relationship? Limnology and Oceanography, 45 (6): 1213-1223.

Haitjema, H.M., 1995, Analytic element modeling of groundwater flow: Academic Press, San Diego, 394 p.

Holdren, C., Jones, W. and Taggart, J., 3rd edn, 2001, Managing lakes and reservoirs: N. Amer. Lake Management Soc. and Terrene Inst., Madison, Wis., 381 p.
Lillie, R.A. and Mason, J.W., 1983, Limnological characteristics of Wisconsin lakes: Wisconsin Department of Natural Resources Tech. Bulletin No. 138, 116 p.

Omernik, J.M., Chapman, S.S., Lillie, R.A., and Dumke, R.T., 2000, Ecoregions of Wisconsin: Transactions of the Wisconsin Academy of Sciences, Arts, and Letters, vol. 88, p. 77-103.

Panuska, J.C., and Kreider, J.C., 2002, Wisconsin lake modeling suite program documentation and user's manual, Version 3.3 for Windows: Wisconsin Department of Natural Resources PUBL-WR-363-94, 32 p. [Available online through the Wisconsin Lakes Partnership: accessed December 19, 2002, at URL http://www.dnr.state.wi.us/org/water/fhp/lakes/ laketool.htm]

Porterfield, George, 1972, Computation of fluvial-sediment discharge: U.S. Geological Survey Techniques of WaterResources Investigations, book 3, chap. C3. 66 p.

Robertson, D.M., Goddard, G.L., Helsel, D.R. and MacKinnon, K. L., 2000, Rehabilitation of Delavan Lake, Wisconsin: Lake and Reservoir Management, 16 (3): 155-176.

Robertson, D.M., Goddard, G.L., Mergener, E.A., Rose, W.J., and Garrison, P. J., 2002, Hydrology and water quality of Geneva Lake, Walworth County, Wisconsin: U.S. Geological Survey Water-Resources Investigations Report 02-4039, 73 p.

Robertson, D.M., and Lenz, B.N., 2002, Response of the St. Croix River Pools, Wisconsin and Minnesota, to various phosphorus-loading scenarios: U.S. Geological Survey Water-Resources Investigations Report 02-4181, 36 p.

Robertson, D.M. and Roerish, E.D., 1999, Influence of various water-quality sampling strategies on load estimates for small streams, Water Resources Research, Vol. 35, No. 12, p. $3747-$ 3759.

Robertson, D.M., and Rose, W.J., 2000, Hydrology, water quality, and phosphorus loading of Little St. Germain Lake Vilas County, Wisconsin: U.S. Geological Survey Water-Resources Investigations Report 00-4209, 8 p.

Robertson, D.M., Rose, W.J., and Saad, D.A., 2003, Water quality and the effects of changes in phosphorus loading to Muskellunge Lake, Vilas County, Wisconsin: U.S. Geological Survey Water-Resources Investigations Report 03-4011, 18 p.

Walker, W.W., 1996, Simplified procedures for eutrophication assessment and prediction: U.S. Army Corps of Engineers, Instruction Report W-96-2, variously paginated.

Welch, E.B. 1992. Ecological Effects of Wastewater; applied limnology and pollutant effects, 2nd edition. Chapman and Hall, London, 425 p.

Wisconsin District Lake-Studies Team, 2002, Water-quality and lake-stage data for Wisconsin lakes, Water Year 2001: U.S. Geological Survey Open-File Report 02-135, 149 p.

Wisconsin Department of Natural Resources, 2001, Wisconsin lakes: Wisconsin Department of Natural Resources, PUB FH-800, 180 p. 